\title{
Pelkistettyä todellisuutta
}

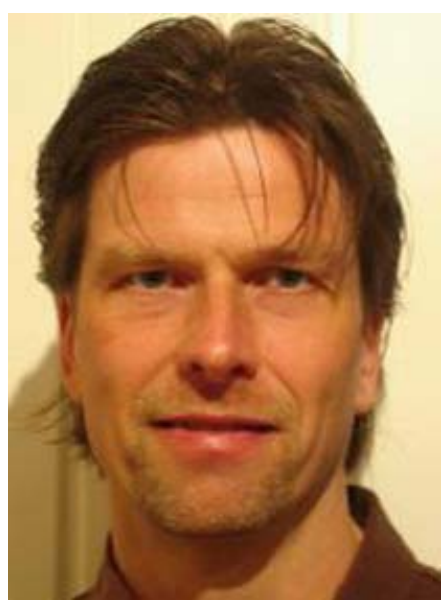

Elämme rajattoman dynaamisessa suuren globaalin murroksen kyllästämässä informaatioajassa, jossa kaikki muuttuu täysin ennakoimattomasti koko ajan. Myös aikuiskasvatusorganisaatioiden toimintaympäristöt muuttuvat jatkuvasti ja ennakoimattomasti. Mikään ei ole kuin ennen! Aikuiskasvatuksen opinnot ovat tärkeä osa omaa inhimillistä koulutus- ja identiteettipääomaani. Freireni, Mezirowini ja Jarvisini aikoinaan luettuani en kykene nielemään yllä esitetyn kaltaisia väitelauseita niitä kriittisesti reflektoimatta, omaa kantaani niihin muodostamatta. Myös muut ihmis- ja yhteiskuntatieteelliset opintoni antavat tarvittavat välineet niiden paikkansa pitävyyden omakohtaiseen koetteluun.

Kaikki muuttuu mutta mikään ei ole uutta. Luin vasta kesälomalla mediassa keväällä paljon keskustelua herättäneen professori Pekka Himasen innovaatioraportin ”Suomalainen unelma”. Se ei alakaan science fictionmaisilla kuvauksilla tulevaisuudesta, jossa emme enää itseämme aikuisiksi tai ihmisiksi tunnistaisi. Raportin prologi alkaa sata vuotta vanhalla Akseli Gallen-Kallela sitaatilla, jossa keskeistä on usko uuden renessanssin tuloon. Jo raportin pintapuolinen selaileminen paljastaa kiireiselle lukijalle sen, että kaikki on aivan kuin ennenkin. Stanfordin yliopiston ympärille kasvanut Piilaakso onkin vain antiikin Ateenan Agoran kehittyneempi versio. Innovaatioraportti on luetteloineen, toistuvine järjestystaulukkoineen sekä maapallo- ja muina karttoineen hyvin suomalaisen oppikirjamainen. Välillä asioiden esittäminen karttojen avulla tuntuu jopa aliarvioivan lukijan hahmotuskykyä. Provosoidun kysymään itseltäni: ”Onko filosofi kirjoittanut maantieteen oppikirjan?” Myöskään raportissa esitetyn "uuden” oppimisfilosofian lähtökohdat ja peruselementit eivät huikaise innovatiivisuudellaan. Sokrateen vertauskuva opettajasta kätilönä, ”jonka tehtävänä on auttaa toista synnyttämään omista lähtökohdistaan” (s. 104) on tutun turvallinen.

Etenkin talouden globalisaation sanotaan nakertaneen kansallisvaltio instituution toiminnan perustaa ja uskottavuutta. Mutta miten on laita sellaisten instituutioiden kuin tiede ja yliopisto, aikuiskasvatuksen tieteenala, aikuiskoulutus ja vapaa sivistystyö? Onko niistä enää iloa ja hyötyä jatkuvan epävarmassa informaatioajassa? Vai edustavatko ne vanhakantaisia ja jäykkiä periaatteita ja rakenteita, joiden toiminta olisi joka virtaviivaistettava tai ulkoistettava?

Yksi esimerkki perustavaa laatua olevien yhteiskunnallisten rakenteiden muuttumattomuudesta ja niiden vaikutuksesta oman elinikäni aikana on aikuiskoulutukseen osallistumista ja osallistumattomuutta selittävät tekijät. Kuten Ari Antikainen ja Arja Huusko artikkelinsa lopussa toteavat, selittyy aikuiskoulutukseen osallistumisen kasvu siirtymällä teollisesta yhteiskunnasta tiedon ja oppimisen yhteiskuntaan. Mutta erot osallistumisessa ja tietotekniikan käytössä aikuisiällä selittyvät edelleen (myös) vanhojen sosiaalisten 
jakojen perusteella. Vaikka keskustelu (yhteiskunta)luokista ja niiden merkityksestä on meillä rajoittunut puheeseen keskiluokasta tai luovasta luokasta saattaa yhteiskunnan syvärakenne paljastua pintaa perinteisemmäksi. Isossa-Britanniassa, tai tarkemmin määriteltynä Englannissa on käsittääkseni edelleen käytössä viisiportainen asteikko: yläluokka, ylempi keskiluokka, keskiluokka, alempi keskiluokka ja alaluokka. Ruotsissa puolestaan käytetään tänäkin päivänä meillä lähes tuntematonta luokkaretken (klassresa) käsitettä. Ruotsinsuomalainen, viime vuonna Ruotsin kirjallisuuden ”Finlandia palkinnon" saanut Susanna Alakoski totesi taannoin luokkaerojen olevan ruotsalaisille edelleen hyvin kiusallinen asia. Alakoski on itsekin luokkaretkeläinen. Hänen kuten muiden luokkaretkeläisten retkilippuna toimii akateeminen tutkinto.

Globaalin kilpailun epävarmoissa ja jatkuvasti muuttuvissa toimintaympäristöissä sanotaan usein korostavan ja vahvistavan johtajuuden merkitystä. Toteamus on sikäli paradoksaalinen, että mikäli nykyajan organisaatiot ovat matalia ja verkostomaisia, valta ja vastuu hajautettua, ei niissä johtajia perinteisessä merkityksessä edes tarvita. Tarvitaan ainoastaan koordinaattori, joka pystyy pitämään löyhän verkoston kasassa, sekä analyytikko, joka kykenee havainnoimaan toimintaympäristössä tapahtuvat merkittävät muutokset ja välittämään ne kootusti organisaation jäsenille. Itse asiassa yrityksissä ja organisaatioissa saattaa johtajuuden suhteen vallita sama tilanne kuin yhteiskunnassa yleisimminkin. Vaikka rakenteita on kevennetty ja toimintaperiaatteita virtaviivaistettu eivät esimerkiksi koulutukseen tai työtehtävien määrittelyyn perustuvat statuserot tai valta- ja johtosuhteet organisaatioiden jäsenten välillä ole kaventuneet saati kadonneet. Ainakin oma työorganisaationi toimii tänään, jopa aiempaa selkeämmin, ylhäältä-alas periaatteella.

Johtaja on nähdäkseni aina myös aikuiskasvattaja. Jokainen opettaja tai kouluttaja on tietyssä mielessä aina ryhmänsä toiminnan johtaja. Ideaali, jossa opettaja korvaa kasvattajan ja myöhemmin ohjaaja opettajan, kuvannee ainakin osin vuosikymmenten varrella tapahtunutta muutosta johtajuuden tarkastelussa ja tutkimuksessa. Vesa Huotarin artikkelissa sekä Keijo Räsäsen ja Janne Tienarin siihen kirjoittamassa vastineessa paneudutaan johtajuuteen tutkimuskohteena ja koulutussisältönä. Tämän lisäksi niissä tarkastellaan myös yleisimmin tieteenteon lähtökohtia sekä tiedettä ylläpitävien ja sen saavutuksia välittävien instituutioiden toimintaperiaatteita. Olen lukenut kumpaakin tekstiä korvaamalla johdonmukaisesti johtajuuden käsitteen aikuiskasvatuksen, MBA-koulutuksen aikuiskoulutuksen käsitteellä. Artikkelista "Tieteellisyys - kanto aikuiskoulutuksen kaskessa” ei välttämättä välity kovinkaan mairittelevaa kuvaa lehtemme edustamasta tieteenalasta.

\section{PETRI SALO}

psalo@abo.fi 